\title{
PROBLEM-BASED MATHEMATICS TEACHING KITS INTEGRATED WITH ICT TO IMPROVE STUDENTS' CRITICAL THINKING ABILITY IN JUNIOR HIGH SCHOOLS IN MEDAN
}

\author{
Waminton Rajagukguk and Erlinawaty Simanjuntak \\ FMIPA State University of Medan \\ email:warajagukguk@gmail.com
}

\begin{abstract}
This study was aimed to develop a set of integrated problem-based mathematics teaching kits implemented with ICT to improve the critical thinking ability of junior high school students. The study used 4-D learning device development model (define, design, develop, disseminate). The data were collected through the observation of the learning process and students' activity, students' questionnaire responses, and a critical thinking ability test. The findings showed that mathematics teaching materials consisting of teaching kits as a teachers' handbook based on ICT integrated problem-based materials completed with lesson plans, worksheets, and the use of media learning were appropriate to use.Based on the test results conducted in the field, the teaching kits can enhance the students' critical thinking ability. The findings showed that the average gain in two schools was in the range of $g>0.7$, which means that the students' critical thinking ability belonged to the high category, while that of the third school was in the range of $0.3 \leq \mathrm{g} \leq 0.7$ at 0.62 which means the students' critical thinking ability belonged to the fair category.
\end{abstract}

Keywords: learning device, information communication technology (ICT), critical thinking

\section{PERANGKAT PEMBELAJARAN MATEMATIKA BERBASIS MASALAH TERINTEGRASI ICT UNTUK MENINGKATKAN KEMAMPUAN BERPIKIR KRITIS SISWA SMP KOTA MEDAN}

\begin{abstract}
Abstrak: Penelitian ini bertujuan untuk mengembangkan perangkat pembelajaran matematika berbasis masalah terintegrasi dengan ICT untuk meningkatkan kemampuan berpikir kritis siswa SMP. Penelitian menggunakan model pengembangan perangkat pembelajaran model 4-D (define, design, develop, disseminate). Data penelitian diperoleh melalui pengamatan proses pembelajaran dan aktivitas siswa, angket respon siswa, dan tes kemampuan berpikir kritis. Hasil penelitian menunjukkan bahwa perangkat pembelajaran yang terdiri atas bahan ajar matematika sebagai buku pegangan guru berbasis masalah yang terintegrasi dengan ICT disertai RPP, LKS, dan media pembelajaran layak digunakan. Berdasarkan hasil uji coba di lapangan, perangkat pembelajaran tersebut dapat meningkatkan kemampuan berpikir kritis siswa. Hasil penelitian menunjukkan bahwa rata-rata gain pada dua sekolah dimana sekolah pertama dan kedua didapat rentang $\mathrm{g}>0,7$ yang artinya kemampuan berpikir kritis siswa pada kategori tinggi, sedangkan pada sekolah yang ketiga rentang $0,3 \leq \mathrm{g} \leq 0,7$ yaitu 0,62 yang artinya kemampuan berpikir kritis siswa mengalami peningkatan pada kategori sedang.
\end{abstract}

Kata Kunci: perangkat pembelajaran, ICT, berpikir kritis

\section{INTRODUCTION}

A learning process is an interaction or reciprocal relationship between the teacher and the students in a unit of learning. Slavin (1997) proposes that in the learning process, the role of a teacher is merely giving the knowledge to the students. The students need to develop their own knowledge by facilitating their own brain to think. The teacher may help this process, by teaching the designed information to be more 
meaningful to the students and relevant with their needs. In the learning process, the teacher's task is to choose the learning approach as well as the appropriate media which match the characteristics of the material given in order to meet the objective of learning. A teacher's role does not only provide learning material, but more than that, a teacher may also act as a learning designer. Therefore, a teacher is expected to be able to plan and produce teaching kits, that cover Lesson Plans, Students' worksheet, and media which are able to activate the students in such a way that the learning process will be more effective and interesting in order to make the students comfortable in learning and can arouse the students' attention to learn the material. In other words, the students respond positively to the lesson. Harjanto (2003: 17-17) argues that planning will facilitate the teacher to decide the target accomplishment before the planning was made, to decide the steps that need to be carried out during the process, and to facilitate evaluation after the implementation process.

In the learning process, there are four essential components that affect students' learning achievemen. They are learning device, learning environment, media and learning resources, as well as the teacher as the learning subject (Kurniawati 2011:27). Thus, a learning model, media and learning instruments are required to improve the students' learning achievement. One of the media which can be used in learning mathematics in junior high schools is ICT, because junior high school students generally have been familiar with technology, especially computer and internet utilization. Problem-based learning implementation integrated with ICT will develop students' logical thinking pattern in order that studentscan think critically. These concerns are in accordance with Moore's argument (2009) saying that computer use in the learning process could help the students to develop basic skills and critical thinking ability. In mathematics learning, media application in learning can establish understanding and mathematics material mastery. Learning media can make the message and information presentation clearer and to reinforce the process so that students get better learning achievement (Arsyad, 2010:248-249). The teaching method applied using the lecturing method without the use of media will make the learning activities only rely on verbal language (Krimanto, 2010). Students will not be active in the teaching learning process. Students with visual and kinesthetic learning styles will get less attention from the teacher. Thus, the role of media in the learning process is very important, because it can make students more capable and easily achieve the learning objectives.

A Mathematics learning activity is expected to be an interactive activity between teacherto-student, student-to-student and student-toteachers in teaching mathematical concepts. This interaction can be applied through the Problem Based Learning (PBL) or "Pembelajaran Berbasis Masalah”. PBL learning materials are characterized by the existence of the problem (Arends, 2008). Problem-solving skills are influenced by the ability to think critically and logically. Mulyana (2008) says that the ability to think critically and creatively plays an important role when the students were on an episode of problem solving. By the time the students understand the problem, they must use their critical thinking ability, such as identifying the assumptions given, formulating mathematical models and so on. In addition, students must use their creative thinking ability, such as formulating mathematical models in several ways. And, they should their critical thinking ability when they have o choose the most appropriate mathematical models to solve the problems.

Critical thinking is often mentioned as human ability that is so common in everyday life. Critical thinking is one-step-higher-level thinking. Costa (Liliasari, 2000:136) categorizes the complex thining processes or higherlevel thinking into four which include problem solving, decision making, critical thinking, and creative thinking. The nature of complexity and context of higher-level thinking abilitycannot be taught by using the approaches which are designed to teach concrete ideas and skills, but can only be done by using a problem solving 
approach by the students themselves (Stanis, 2009). In the study of mathematics, one way to develop higher order thinking ability isby utilizing instructional media or ICT.

Churchill(2009) stated that the ICT transform a new dimension in teaching effectiveness by enabling the teachers to apply ICT even though it seems impossible to apply it in a traditional classroom. Nevertheless, teachers need professional training to be able to integrate existing technologies in the syllabus. Using modern technology alone or without considering the theory of learning will not be effective as what Mesrabadi (2011) said that there is no significant difference found between the experimental group using power point for presentations and the control group. Moreover, the results indicate that the use of Power Point has no significant effect on the cognitive factors and the memorization of the subject matter, the understanding of texts and the ability to use information. Teachers need to be trained in the application of ICT in learning. This is in accordance with the opinion of Baylor and Ritchie (2002). Teachersare expected to be able to integrate ICT in teaching; they need to use ICT for certain subjects. Trainers need to give both practice and theory about the use of ICT through direct experience. In addition, teachers should be aware that introducing ICT instruments for teaching does not only change the instruments for teaching, but they need to change theway of teaching and the materials to be taught (Harris et.al, 2009). Graham et. al. (2009) state that teaching with ICT alone does not transform the teachers to teach properly, because they only learn how to use the ICT. They may not be able to use the tool effectively to develop student learning. Being an integrated ICT teacher means having ICT skills and developing an understanding of the complex relationship between pedagogy, content and ICT (Hughes, 2005). In fact, without the basic knowledge, no one can use advanced educational technology effectively. Resta (2002) said that the UNESCO education expert has confirmed if the teachers did not have a model application of technology in the classroom, it is impossible for them to use ICT effectively.

Teachers need to be trained and to involved in the problem solving activity so that they can see that it is possible for them to integrate problem solving with ICT. Jimoyannis (2020) states the appropriate learning in the 21 st century requires students to be able to use ICT, not only to expand the ability to memorize facts, but also to use problem solving in the real world. Koehler and Mishra (2005) recommends that involving teachers in problem solving in collaboration with ICT is an effective way to learn about ICT and the integration process of ICT which can develop Technological Pedagogical Content Knowledge (TPACK) as descrybed by Shulman (1986). TPACK helps to establish the main idea through Technological involvement. Koehler, Mishra, and Yahya (2007) suggested that teachers must work cooperatevely within the design team to establish TPACK by designing an ICT solution for pedagogical problems.

The main challenge in the application of ICT in learning is that "both the teacher and students are learning new skills related to ICT" (UNESCO, 2003:20). However, to master new skills takes time and and requires a high costby inspecting the learning resource or components of the learning system issues related to the application of ICT in teaching concerning educators/teachers, message/curriculum, hardware, software, information networks, development of learning package, evaluation, funding, etc. (Gafur, 2001:92; APEID, 1994:19). Learning technologies can be prepared to utilize the proper strategy and optimized to improve the quality, efficiency, and effectiveness of education and learning at various levels of education units (Surjono, et.al, 2010).

Based on the above explanation, the purpose of this research is to produce teaching kits with integrated ICT-based learning problems that can improve critical thinking ability of junior high school students. The teaching kits developed in this study consists of: (1) teachers' handbook; (2) Lesson Plan; (3) Students Worksheet; (4) ICT Media utilizing Macro Media Flash. 


\section{METHOD}

This experiment was carried out using an experimental method to objectively revealthe improvement of students' critical and creative thinking skills as a result of the treatment provided in the form of multimedia utilization of ICT in learning mathematics.

The data were collected by using critical and creative thinking ability tests and the learning activity recordings to find out the students' attitude in the implementation of learning mathematics in class using multimedia ICT based on the related theories.

This type of research is developmental research that employed software development learning models, using the model developed by Thiagarajan, Summel and Summel (1974) namely 4-D model (define, design, develop, disseminate).To explore the causes of low problemsolving ability and the lack of of students' learning independence, thus a simple method called fishbone diagram analysiswas used as shown in Figure 1.

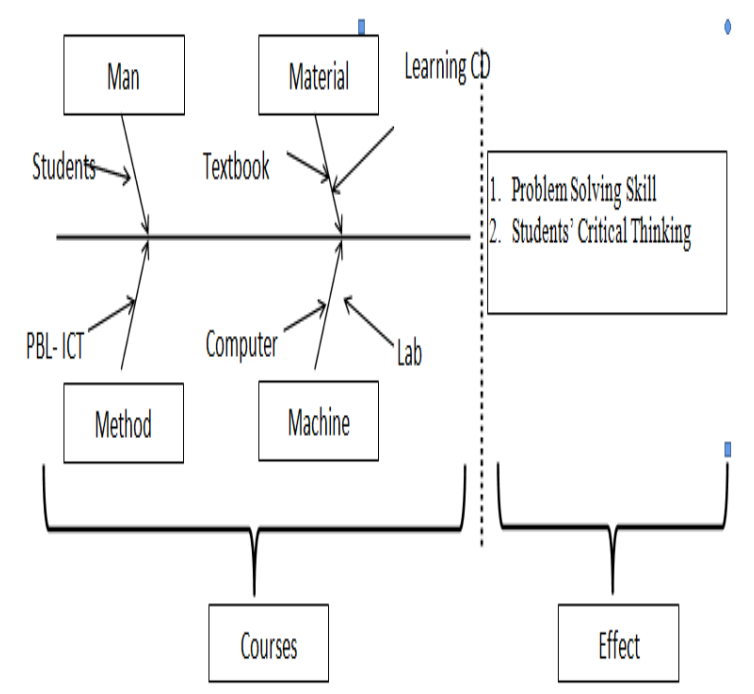

Figure 1. Fishbone Research

There are several components that can affect the competence of the students to understand the problem-solving skills such as human resources, materials, methods and equipment. In terms of human resources component, the students' critical thinking and problem solving skills will be examined, in terms of material component; media learning will be developed by the assist of ICT. in terms of methodological component, the learning model will be examined which related to the problems that can be assisted by ICT.

In ordertofind out the reasons of low problem-solving ability a simple methods were used as flow diagram in Figure 2.

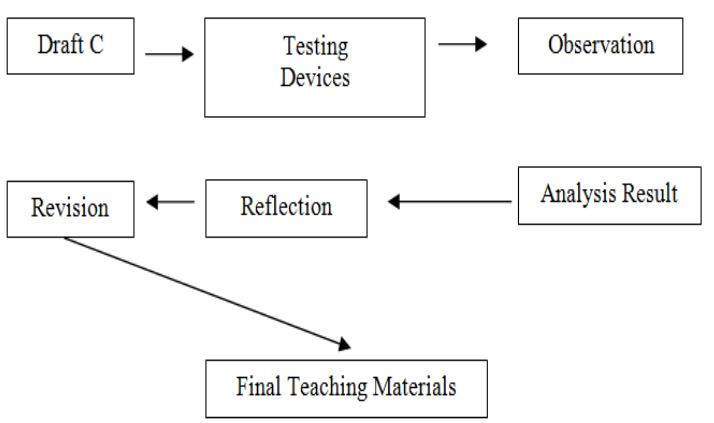

\section{Figure 2. Flow Diagram of Pilot Testing}

Data were obtained through the following steps. (1) The observation of the learning process that teachers do as an observer. (2) The students' activity observation by observers. (3) Students' Questionnaire responses about the opinion on the activities and learning tools that are given to each student after the end of the last meeting. (4) Critical thinking ability test which were conducted in the last meeting.

The data analysis technique consists of: (1) the validity of the learning device used analysis experts deal with statistical analysis through interrater (Asmin, 2012:239); criteria for assessment of the level of agreement between observers by Borg and Gall (1983:479), that the level of agreement of 0.70 to 0.80 are adequate (valid); (2) the student response data obtained through the questionnaire were analyzed by percentage; (3) to see an increase in students' critical thinking ability, judging from the results of the initial test (pre-test) and final test (post-test) were analyzed by calculating the $\mathrm{N}$-gain with $\mathrm{N}$-gain formula proposed by Hake (1999) as follows;

$$
\begin{aligned}
& \langle g\rangle=\frac{\langle\text { gain }\rangle}{\langle\text { gain }\rangle_{\max }}=\frac{\langle\text { posttes }\rangle-\langle\text { pretes }\rangle}{100-\langle\text { pretes }\rangle} \\
& \mathrm{G}<0.3 \quad \text { Low category } \\
& \leq 0.3 \mathrm{~g}<0.7 \quad \text { Medium category } \\
& \geq 0.7 \text { g High category }
\end{aligned}
$$




\section{RESULTS AND DISCUSSION}

\section{Instrument of Learning Validity}

In accordance with the objectives and targets which will be achieved in this research specifically to develop learning device such as learning materials, students worksheet (LKS) and Lesson Planning (RPP) of mathematics in junior high school grades VII.

The results of the validity testing of the learning instrument are shown in Table 1.

\section{Tabel 1. Validity Test Results of Learning} Instrument

\begin{tabular}{llll}
\hline No. & Instrument & Validiy & \multirow{2}{*}{ Category } \\
& Components & Level (r) & \\
\hline 1. & Lesson Plan & 0,8156 & Valid \\
2. & Students' Worksheet & 0,7332 & Valid \\
3. & Media & 0,7202 & Valid \\
\hline
\end{tabular}

The result of validity assessment shows that there is no significant changes for the validated learning instruments, therefore the learning instruments is considered valid so the learning instruments is appropriate to be tested. This correspond the criteria proposed by Borg \& Gall (1983:479) (1983:479) that the level of agreement of 0.70 to 0.80 is adequate which means that the learning instruments are adequate to use. These results are in accordance with the criteria set forth by Nieeven (in Trianto 2010: 24) that a material (the learning) is said to be valid if all the experts who validate the instrument assessed to be valid. In relation with Arikunto (2013: 167) said that an instrument has validity if an analysis is in conformity with the contents and the aspects disclosed. The results of this study are also consistent with the results of research conducted by Sunismi and Mulin'man (2012: 215) concluded that the teaching materials (textbooks and instructionalCD) are effectively used in mathematics.

\section{Instruments of Learning Testing Results}

Pilot testing had been conducted in three different schools as sampled schools. Meanwhile learning session in every school has reached four meetings. At the first meeting pretest were conducted and posttest at the end of the fourth meeting.

Based on the observations during the learning process takes place, in general, the learning process goes expeditious; the displayed media also attracted the attention of students and helped them to understand the material better. The students were actively engaged with their friends in their team discussing the given students worksheet, despite they frequently felt that they were running out of time to discuss the task given. Regarding this matter, according to the observational result, the students did not understand the context, less attention to teacher's direction and tended to immediately answer the student's worksheet.

Bishop (2000) suggested that there are still a few teachers who understand how far the effect of learning which has been implemented and how to design mathematics learning in order to connect the values of mathematics to the students.

In order to find out the difference in critical thinking ability of students before and after the treatment, $\mathrm{t}$-test analysis was used on the pre-test and post-test data both on experimental and control classes in each school. The results are in Table 2.

In Table 2 above shows that scores in all groups had a significantly smaller value of alpha $(\alpha=0,05)$ thus it can be concluded that in each population group there are differences in pretest and posttest results of critical thinking ability. There are differences within the group of schools in critical thinking ability after the treatment were given.

Tabel 2. Paired Samples Test

\begin{tabular}{lllll}
\hline & & T & df & $\begin{array}{l}\text { Sig. (2- } \\
\text { tailed) }\end{array}$ \\
\hline Pair 1 & $\begin{array}{l}\text { School A Pre-test - } \\
\text { School A Post-test }\end{array}$ & -16.424 & 24 & .000 \\
Pair 2 & $\begin{array}{l}\text { School B Pre-test - } \\
\text { School B Post-test }\end{array}$ & -15.299 & 24 & .000 \\
Pair 3 & $\begin{array}{l}\text { School C Pre-test - } \\
\text { School C Post-test }\end{array}$ & -17.654 & 24 & .000 \\
\hline
\end{tabular}


Notes:

School A is SMP Negeri 35 Medan

School B is SMP Negeri 27 Medan

School C is SMP Swasta Gajah Mada

\section{Observation Result on Instrument Testing}

In general, the learning process ran swiftly, the displayed learning media also attracted the attention of students and helped them understand the material better. The students were actively engaged with their friends in their team discussing the given students worksheet, despite they frequently felt that they were running out of time to discuss the task given. Regarding this matter, according to the observational result, the students did not understand the context, less attention to teacher's direction and tended to immediately answer the student's worksheet.

To see the difference in the students' critical thinking ability which is significant to the research hypothesis that assumes there is no difference in treatment which was carried out in every school, thus the One-way ANOVA analysis were used. Based on the data processing with SPSS towards post-test scores the data were obtained as shown in Table 3.

From the table above, it can be seen that the score is $(0,593)>\alpha(0,05)$ it shows that there's no significant differences of critical thinking skill in every population, it means that the escalation happened in all population with almost equal extent in the designated junior high schools.

\section{Students Critical Thinking Ability Level}

Critical thinking is a cognitive process associated with the use of reasoning. Learn to think critically means using mental processes, such as attention, categorizing, selection, assess and decide. The ability to think critically provides a proper direction in thinking and working, and assist in determination of some kind of relations with other things more accurately.

Critical thinking skills include: interpretation, analysis, evaluation, explanation, understanding the logical relationships between ideas detect inconsistencies and errors common, in giving reasons as well as to identify, construct and evaluate argument. Critical thinking skills in this paper are the ability to identify concepts, generalize a situation related to a concept, and problem solving skills. The ability is measured by a test of critical thinking skills, which taken in a test with descriptive form. The escalation of thinking ability is said to be effective if the students achieved an increase classically, which means if there were $89 \%$ students or more reached out for $65 \%$ of the total maximum scores. Classical escalation in pre-test result in three schools were less than $85 \%$, thus, classically on the results of students' pre-test thinking ability did not meet the required criterion. In accordance with the theory of Watson and Groh (2001, pp.20-21) that the problembased learning ensure the students will be able to do several things, some of them are the learning ability to think critically to solve problems.

While on the post-test results, based on Table 4 obtained more than $85 \%$ of students at all three schools have achieved an increase classically. These results are consistent with Noer's result (2009) that the increase in students' mathematical critical thinking ability that receive the mathematical study by using problem-based learning were better than the students who study mathematics conventionally.

Tabel 3. Univariate Analysis of Variance

\begin{tabular}{llllll}
\hline Source & Type III Sum of Squares & df & Mean Square & F & Sig. \\
\hline Corrected Model & $126.000^{\mathrm{a}}$ & 2 & 63.000 & .527 & .593 \\
Intercept & 475212.000 & 1 & 475212.000 & 3972.975 & .000 \\
Schools & 126.000 & 2 & 63.000 & .527 & .593 \\
Error & 8612.000 & 72 & 119.611 & & \\
Total & 483950.000 & 75 & & & \\
Corrected Total & 8738.000 & 74 & & & \\
\hline
\end{tabular}

a. R Squared $=.014$ (Adjusted R Squared $=-.013$ ) 
Tabel 4. The percentage of critical thinking ability increment in every school

\begin{tabular}{|c|c|c|c|c|c|c|c|c|c|c|c|c|}
\hline \multirow{3}{*}{ Category } & \multicolumn{4}{|l|}{ SMPN 35} & \multicolumn{4}{|l|}{ SMPN 27} & \multicolumn{4}{|c|}{ SMPS Gajah Mada } \\
\hline & Pre-test & & Post-test & & Pre-test & & Post-test & & Pre-test & & Post-test & \\
\hline & $\begin{array}{l}\text { Students' } \\
\text { sum }\end{array}$ & $\%$ & $\begin{array}{c}\text { Students' } \\
\text { sum }\end{array}$ & $\%$ & $\begin{array}{c}\text { Students' } \\
\text { sum }\end{array}$ & $\%$ & $\begin{array}{c}\text { Students' } \\
\text { sum }\end{array}$ & $\%$ & $\begin{array}{c}\text { Students' } \\
\text { sum }\end{array}$ & $\%$ & $\begin{array}{c}\text { Students' } \\
\text { sum }\end{array}$ & $\%$ \\
\hline Effective & 5 & $0 \%$ & 22 & $8 \%$ & 4 & $6 \%$ & 23 & $2 \%$ & 3 & $2 \%$ & 23 & $2 \%$ \\
\hline $\begin{array}{l}\text { Not } \\
\text { Effective }\end{array}$ & 20 & $0 \%$ & 3 & $2 \%$ & 21 & $4 \%$ & 2 & $8 \%$ & 22 & $8 \%$ & 2 & $8 \%$ \\
\hline Total & 25 & $00 \%$ & 25 & $00 \%$ & 25 & $00 \%$ & 25 & $100 \%$ & 25 & $00 \%$ & 25 & $00 \%$ \\
\hline
\end{tabular}

Tabel 5. Achievement Category of N-gain Critical Thinking Ability

\begin{tabular}{llll}
\hline No. & Name of School & N-gain & Category \\
\hline 1. & SMP N 35 Medan & 0,74 & High \\
2. & SMP N 27 Medan & 0,72 & High \\
3. & SMP S Gajah Mada & 0,62 & Medium \\
\hline
\end{tabular}

From the result of data obtained by conducting the tests shown that the average gain in two schools were in the range $\mathrm{g}>0.7$, which means the students' critical thinking ability fell under high category, while SMP S Gajah Mada Medan N-gain is in the range of $0,3 \leq \mathrm{g} \leq 0,7$ that is 0.62 , which means the students' critical thinking ability climbed up to medium category. The increment of the students' ability in critical thinking were affected by the use of problembased learning instrument in accordance with the research results conducted by Nurina Happy (2014) stating that the Problem-based learning is more effective than conventional learning in terms of (1) mathematical critical thinking ability; (2) mathematical creative thinking ability; and (3) students' self-esteem.

\section{DataAnalysis of Students Questionnaire Res- ponse}

Based on the students' questionnaire response in the three school of problem-based mathematics learning device integrated with ict, its found that there are two types of the students' responce, namely positive response and negative response. Positive response is known from the students stating that it is more effective studying in terms of mathematical learning device. Negative response is known from the students stating that it is not more effective studying in terms of the mathematical learning device. The result of data analysis towards the students' questionnaire response as shown in Table 6.

Table 6. Data Analysis of Students Questionnaire Response

\begin{tabular}{llll}
\hline No. & \multicolumn{1}{c}{ Aspek yang Diamati } & \multicolumn{2}{c}{ Persentage } \\
\hline 1 & How do you feel to the learning device: & Effective & Not effective \\
& a. Learning of Materials & $87 \%$ & $13 \%$ \\
b. Students' learning sheet & $88 \%$ & $12 \%$ \\
c. Media of Learning & $91 \%$ & $9 \%$ \\
d. Activity in the class & $84 \%$ & $16 \%$ \\
e. Teachers' Teaching Process & $87 \%$ & $13 \%$ \\
2. What is your response to the learning device: & Common & Uncommon \\
a. Learning of Materials & $83 \%$ & $17 \%$ \\
b. Students' Learning Sheet & $85 \%$ & $15 \%$ \\
c. Media of Learning & $88 \%$ & $12 \%$ \\
d. Activity in the class & $80 \%$ & $20 \%$ \\
e. Teachers' Teaching Process & $85 \%$ & $15 \%$ \\
Are you interested in learning Problem-Based & Mathematics & Interested & Not interested \\
Learning Device Integrated With ICT ? & $93 \%$ & $7 \%$ \\
\hline
\end{tabular}


Based on the table above, it can be shown that the students' questionnaire response towards all the components of learning device which consists of learning materials, studens' learning sheet, media of learning, the activity of the learning process and the teaching process in learning Problem - Based Mathematics Learning Device Integrated with ICT is about $80 \%$.

This research is supported by the research of Murwaningsih, Erika and Nuryani (2014:471) stated that the students' questionnaire response to the process of learning device show that there are $22(91,67 \%)$ of 24 components of learning device which has positive response from the students.

This research shows that every aspects of the positive students' questionnaire response in learning the problem based mathematics learning device integrated with ICT is increased and the students as a self - directed learner. This statement is supported by the Problem Based Learning in the class is not only focus on the problem but also how to create the chance to thestudents to construct the knowledge of learning device through the effective social interaction.(Tan, 2003,p.22).

\section{CONCLUSION}

Based on the research and the result of the Problem-Based Mathematics Learning Device Integrated With ICT, can be conclude as follows.

- The Strategy of Problem-Based Mathematics Learning Device Integrated With ICT as a media for a teacher who held this learning process in contextual.

- The Problem - Based Mathematical Learning Device Integrated with ICT is more effective to do and can increase the significance of the students' critical thinking ability.

- The students' questionnaire response to the Problem-Based Mathematical Learning Device Integrated with ICT is good to apply in a learning process of teaching mathematics.

\section{ACKNOWLEDGEMENT}

The writer say thanks to DP2M as the Director of the Education Department who give a chance to facilitate the process of this research in material and supports which in Hibah Bersaing in Surat Perjanjian Penelitian Nomor: 062/UN33.8/LL/2014, April, 01 ${ }^{\text {st }}$ 2014. Hopefully this research can give the effectiveness in Learning and Teaching Process, especially in Education.

\section{REFERENCES}

Arends, I. Richard.2008.Learning to Teach: Belajar untuk Mengajar. Terjemahan: Helly Prajitmo Soetjipto dan Sri Mulyantini Soetjipto. Yogyakarta: Pustaka Pelajar.

Arikunto, S. 2013. Manajemen Penelitian, Jakarta: Rineka Cipta.

Arsyad, A. 2010. Media Pembelajaran. Jakarta: Raja Grafindo Persada.

Asmin. 2012. Pengukuran dan Penilaian Hasil Belajar dengan Analisis Klasik dan Modern. Medan: Larispa Indonesia.

Baylor, A. L., \& Ritchie, D. 2002. "What Factors Facilitate Teacher Skill, Teacher Morale, and Perceived Student Learning in Technology-Using Classrooms?" Computers \& Education. Vol. 39, No. 4, pp. 395-414. doi: 10.1016/s0360-1315 (02) 00075-1.

Bishop,Alan dkk, 2000.Values In Mathematics Education: Making Vlues Teaching Explicit in the Mathemtaics Classrom. http://www.aare.au//99pap/bis/991888.html.

Borg, W., dan Gall, M. 2003. Educational Research; an Introduction $6^{\text {th }}$ Edition. Boston: Pearson.

Churchill, D. 2009. "Educational applications of Web 2.0: Using Blogs to Support Teaching and Learning”. British Journal of Educational Technology, Vol. 40, No. 
1, pp. 179-183. doi: 10.1111/j.1467-8535. 2008.00865.x.

Graham, C. R., Burgoyne, N., Cantrell, P., Smith, L., St. Clair, L., \& Harris, R. 2009. "TPACKDevelopment in Science Teaching: Measuring the TPACK Confidence of in-Service Science Teachers". Tech Trends, Vol. 53, No. 5, pp. 70-79.

Gafur, Abdul. 2001. "Pendidikan dalam Tantangan Teknologi ICT". Cakrawala Pendidikan: Mei 2001 Th. XX. No.2. pp 9095.

Harris, J., Mishra, P., \& Koehler, M. 2009. 'Teachers' Technological Pedagogical Content Knowledge and Learning Activity Types: Curriculum-Based Technology Integration Reframed". Journal of Research on Technology in Education. Vol. 41, No. 4, pp. 393-416.

Harjanto. 2003. Perencanaan Pengajaran. Jakarta: PT Rineka Cipta.

Hughes, J. 2005. "The Role of Teacher Knowledge and Learning Experiences in Forming Technology-Integrated Pedagogy". Journal of Technology and Teacher Education, Vol. 13, No. 2, pp. 277-302. http://www.editlib.org/p/26105.

Jimoyiannis, A. 2010. "Designing and Implementing an Integrated Technological Pedagogical Science Knowledge Framework for Science Teachers' Professional Development". Computers \& Education, Vol. 55, No. 3, pp. 1259-1269.doi: 10.1016/ j.compedu.2010.05.022

Koehler, M. J., \& Mishra, P. 2005. "What Happens When Teachers Design Educational Technology? The Development of Technological Pedagogical Content Knowledge". Journal of Educational Computing Research. Vol. 32, No. 2, pp. 131152.
Koehler, M. J., Mishra, P., \& Yahya, K. 2007. "Tracing the Development of Teacher Knowledge in a Design Seminar: Integrating Content, Pedagogy and Technology". Computers \& Education, Vol. 49, No. 3, pp. 740-762. doi: 10.1016/j.compedu.2005. 11.012 .

Kurniawati, R. 2011. Meningkatkan Kemampuan Berpikir Kritis Siswa SMA Melalui Metode Pembelajaran Analitik Sintetik. http://ri2nkurniawati.blogspot.com/2011/ 12/meningkatkan-kemampuan-berpikirkritis.html. 22 Februari 2014.

Krimanto, Al dan Agus Dwi Wibawa. 2010. Pembelajaran Kemampuan Pemecahan Masalah Bangun Datar di SMP. P4TK Matematika Yogyakarta: Kementrian Pendidikan Nasional. Direktorat Peningkatan Mutu Pendidikan dan Tenaga Kependidikan.

Liliasari. 2000. "Model Pembelajaran untuk Meningkatkan Keterampilan Berpikir Konseptual Tingkat Tinggi Calon Guru IPA". Proceeding Nasional Science Education Seminar, The Problem of Mathematics and Science Education and Alternative to Solve the Problems. Malang: JICA-IMSTEP FMIPA UM.

Mesrabadi, J. 2011. "Payamadhaye Shenakhti va Atefie Estefade az Slide dar Kelase Dars" [Cognitive and Affective Consequences of Using Slides in the Classroom]. Fanavarie Amouzesh, Vol. 5, No. 42.

Moore, K. D. 2009. Effective Instructional Strategies: from Theory to Practice. London: Sage Publication, Inc.

Mulyana, T. 2008. "Pembelajaran Analitik Sintetik untuk Meningkatkan Kemampuan Berpikir Kritis dan Kreatif Matematik Siswa Sekolah Menengah Atas". Disertasi. Bandung: PPS UPI. 
Murwaningsih, Utami; Erika L.A. dan Nuryani T.R., 2014. "Implementasi Pengembangan Perangkat Pembelajaran Matematika Realistik di Sekolah Menengah Pertama" dalam Cakrawala Pendidikan, XXXIII (3), hlm. 471.

Noer, S. H. 2009. "Peningkatan Kemampuan Berpikir Kritis Siswa SMP melalui Pembelajaran Berbasis Masalah". Makalah Disampaikan pada Seminar Nasional Matematika dan Pendidikan Matematika, di UNY 5 Desember 2009, http://eprints.uny.ac.id/7048/1/P33\%20Dra.\%20Sri\%2 0Hastuti\%20Noer.pdf.

Nurina Happy, Djamilah B.W. 2014. "Keefektifan PBL Ditinjau dari Kemampuan Berpikir Kritis dan Kreatif Matematis, Serta Self-Esteem Siswa SMP". Riset Pendidikan Matematika, Volume 1 (1), hal 48.

Resta, P. 2002. Information and Communication Technologies in Teacher Education, Division of Higher Education. Paris: UNESCO.

Shulman, L.S. 1986. "Those Who Understand: Knowledge Growth in Teaching". Educational Researcher, Vol. 15, No. 4.

Slavin, R.E. 1988. Educational Psychology, Theory into Practice. Englewood Cliffs, N.J: Prentice Hal.

Stanis, Lausamsikan. 2009. Keefektifan Pembelajaran Matematika dengan Model Problem Based Learning dan Model Cooperative Learning Tipe Jigsaw di SMA". Tesis, Program Pascasarjana UNY. http://eprints.uny.ac.id/634/keefektifanpembelajaran-matematika.html.4 Januari 2011.
Sunismi, Mulin, N. 2012. "Pengembangan Bahan Pembelajaran Geometri dan Pengukuran Model Penemuan Terbimbing Berbantuan Komputer untukMemperkuat Konsepsi Siswa". Cakrawala Pendidikan, XXXI (2), hlm.200-216.

Surjono, Herman Dwi \& Gafur, Abdul. 2010. "Potensi Pemanfaatan ICT untuk Peningkatan Mutu Pembelajaran SMA di Kota Yogyakarta”. Cakrawala Pendidikan. Juni 2010, XXIX (2), pp. 161-175.

Trianto. 2010. Mendesain Model Pembelajaran Inovatif-Progresif: Konsep, Landasan dan Implementasinya pada Kurikulum Tingkat Satuan Pendidikan (KTSP). Jakarta: Kencana Prenada Media Grup

Tan, O.S. 2003. Problem-Based Learning Innovation: Using Problems to Power Learning in the 21st Century. Singapore: Cengange Learning.

Watson, G. H.,\& Groh, S. E. 2001. "Faculty Mentoring Faculty: the Institute for Transforming Undergraduate Education". Dalam Duch, B. J., Groh, S.E., \& Allen, D. B. (Eds.). The Power of Problem-Based Learning: a Practical "How to" for Teaching Undergraduate Course in any Discipline. (pp.13-22). Sterling: Stylus Publishing, LLC. Young, E.L., \& Hoffmann 